\title{
Production and characterization of absorbent heat from the bark of residual Brazil nut bark (Bertholletia Excelsa l.)
}

Selma dos Santos Melo ${ }^{1 *}$, Joel Estevão de Melo Diniz ${ }^{2,3}$, Jonilson Heslei Guimarães², Josivan da Silva Costa ${ }^{3}$, Davi do Socorro Barros Brasil ${ }^{4}$, Sílvia Simone dos Santos de Morais ${ }^{2}$, Daímio Chaves Brito², José Carlos Tavares Carvalho ${ }^{3}$, Cleydson Breno Rodrigues dos Santos ${ }^{3}$ and Denilson Luz da Silva ${ }^{1}$

\begin{abstract}
Background: The increasing efforts to reduce the environmental impact on the Amazon's natural resources are focusing on watercourses that pass through effluents with high concentrations of heavy metals. The adsorption by absorbent is one of the methods used to remove metallic ions. In this assignment, the preparation of activated carbon from Brazil nut bark (Bertholletia excelsa l.), which is a waste material produced from the use of seeds in foodstuffs and cosmetics, is shown.

Results: The absorbent was carbonized at $400{ }^{\circ} \mathrm{C}$ in $3 \mathrm{~h}$ and activated at $800{ }^{\circ} \mathrm{C}$ in $2 \mathrm{~h}$, having received the name of $A C 2$, and, the specific area, pore size, real and apparent densities, porosity, scanning electron microscopy (SEM) coupled to energy-dispersive $X$-ray spectroscopy (EDS), X-ray diffraction (XRD), $\mathrm{pH}$, moisture, fixed carbon and surface functional groups by Boehm method and Fourier transformed infrared spectroscopy (FTIR) were characterized. According to the results, the carbon presented alkaline characteristic, mesoporosity, average pore diameters of $2.203 \mathrm{~nm}$ and specific surface area by BET of $464.835 \mathrm{~m}^{2} \mathrm{~g}^{-1}$.

The efficiency of removal was performed in synthetic solutions of copper sulphate (II) pentahydrate $\left(\mathrm{CuSO}_{4} .5 \mathrm{H}_{2} \mathrm{O}\right)$, evaluating the influence of $\mathrm{pH}$, initial concentration of copper solution (II), particle diameter and time contact of the adsorbent in solution. The results of higher removal percentages were to $\mathrm{pH} 5.09$, initial concentration of 50, 100 and $150 \mathrm{mg}^{-1}$ diameter $0.595<\mathrm{D}<1.19 \mathrm{~mm}$ and time contact of $5 \mathrm{~min}$.
\end{abstract}

Conclusions: The Brazil nut bark is shown to be an important bio-waste, being an excellent alternative material for the low-cost production of activated carbon for use in processes involving iterations of adsorption.

Keywords: Absorbent, Brazil nut, Thermal activation

\section{Background}

One of the main problems causing environmental pollution of watercourses is industrial effluents that have high concentrations of heavy metals, with disagreements existing on the maximum values allowed by current legislation. The search for practical, efficient and low cost alternatives has been a constant to circumvent these problems.

Some of the many processes employed to reduce the concentrations of heavy metals in industrial effluents are

\footnotetext{
* Correspondence: selmaengquimica@yahoo.com.br

'Laboratory of Environmental Processes, Federal University of Pará, Rua

Augusto Corrêa, 01, Belém, Pará 66075-110, Brazil

Full list of author information is available at the end of the article
}

adsorption, ion exchange, membrane separation and electrochemistry, and these often become economically unviable because they are costly to industries, and are thus not a priority to invest in as they are processes that may affect profit and production.

Among various techniques, the alternative that has attracted considerable attention is adsorption, since it presents itself as an efficient and economical method in wastewater treatment $[1,2]$.

Adsorption is an effective technique for the purification and dehydration of gases and as a means of fluid fractionating, which are difficult to separate by other means of separation [3]. This process occurs when a 
molecule of solute, present in a solution, accumulates on the surface of a solid due to the action of unbalanced surface forces $[4,5]$. The molecules which are adsorbed at the solid/liquid interface are termed adsorbate, while the solid material is adsorbent [6].

Absorbents are natural or synthetic substances with crystalline structure presenting a high surface area for a given mass. The inner surface of the pore is accessible to a selective adsorbent-adsorbate combination [7].

Among the most commercially used adsorbents one finds activated charcoal, zeolites, silica gel and activated alumina, owing to their high surface areas.

Activated charcoal or activated carbon (AC) is a general name given to a group of carbonaceous materials manufactured to have a highly developed porosity and high surface area. Due to its large adsorption capacity, it is a material that has long been used as an adsorbent to purify, detoxify, filter, discolor, separate or concentrate liquid and gaseous materials in diverse areas such as the food, pharmaceutical, chemical, oil, nuclear and automotive industries, and is also applied in wastewater treatment industries and in the process of potability of water [8].

The first step of activated carbon preparation is the carbonization, which is usually performed in the absence of air at temperatures of 400 to $800{ }^{\circ} \mathrm{C}$. During the carbonization of raw materials, condensation of polynuclear aromatic compounds and the breaking of groups of the chemical chain occurs, resulting in a carbon residue. In this environment, cross-linked reactions take place, which inhibit the development of pre-graphite structure [9]. Two methods can be employed for the activation of charcoal: activation by a chemical process or activation by thermal process, also called physical activation.

In chemical activation, the carbonization and activation occur in a single step, in which the vegetal precursor impregnated with a suitable chemical agent $\left(\mathrm{H}_{2} \mathrm{SO}_{4}\right.$, $\mathrm{H}_{3} \mathrm{PO}_{4}, \mathrm{ZnCl}_{2}$, alkali metals hydroxides etc.), is charred. The great advantage of chemical activation is related to the low energy cost, temperatures in the range 400$800{ }^{\circ} \mathrm{C}$, and high process efficiency. Various studies of chemical activation by inorganic agents such as phosphoric acid, potassium hydroxide and $\mathrm{ZnCl}_{2}$, which have been used in the activation of precursors of agricultural waste, are found in the literature [10].

In thermal activation, $\mathrm{AC}$ is produced from material that has been carbonized, that is, a precursor already heat treated. The carbonized material is activated at temperatures that may range $600-1200{ }^{\circ} \mathrm{C}$ in a flux of water steam or carbon dioxide, or a mixture of both, for between 1 and $10 \mathrm{~h}$. The gasification removes the carbonaceous material within the particles, resulting in the creation of pores and clearing of existing ones, leading to a development of the porous structure of the material [11].
Numerous studies have been performed using residues of Amazon natural plants in the production of activated carbon. Agricultural residues are the most common materials studied for this purpose, since they are renewable, usually available in large quantities and cheaper than other materials used to manufacture a variety of adsorbents [12-14]. According Capobianco et al. (2004) [15], it is possible to develop activated carbon from biomass with pores of nanometer dimensions. The use of biomaterial reduces environmental impact in two ways: removal of the residual biomass, which is a pollutant, from where it was generated or deposited and treatment of the contaminated effluent with this residue [16]. Thus, it becomes feasible to use alternatives to biomass residues, such as the Brazil nut shell, coconut shell, acai berry lump, buriti lump, and cupuaçu peel among others [17].

The Brazil-nut or Pará-nut is the seed of the chestnut tree (Bertholletia excelsa L.) of the botanical family Lecythidaceae, gender Bertholletia, and in consideration of the majesty of its bearing it was called excelsa (species). Exploiting Brazil-nuts became the main economic activity of the Amazon region, following the decline in the exploitation of rubber. This activity has sustained thousands of extractive and a whole oligarchy due to its value [18].

This paper aims to use the residual biomass of Brazilnut for the preparation of physically activated carbon (absorbent) at a temperature of $800{ }^{\circ} \mathrm{C}$ within $2 \mathrm{~h}$. The prepared charcoal had its chemical and physical structure characterized. The proposal to transform these shells into activated carbon may create an ecologically viable destination for these wastes.

\section{Experimental}

\section{Preparation of adsorbent}

The raw material used in preparing the samples of absorbent were the shells of the Brazil-nut (Bertholletia excelsa), a residual material of chestnut processing. Firstly, this material was selected, washed in running water and then dried in an oven (drying and sterilization), model 315 SE of the brand FANEM-Brazil, at a temperature of $105{ }^{\circ} \mathrm{C} \pm 5$ for $24 \mathrm{~h}$. After drying, the material was placed on two ceramic vases, where were charred and calcined in the muffle-type electric furnace of QUIMIS model Q318M24-Brazil.

\section{Production and characterization of AC2 Carbonization}

Carbonization assays of $\mathrm{AC} 2$ were performed in 10 runs and each in duplicate, wherein the previously dried shells were stored in ceramic vessels of $10.8 \mathrm{~cm}$ and $11.8 \mathrm{~cm}$ in diameter and carbonized at $400{ }^{\circ} \mathrm{C} \pm 1$ for $3 \mathrm{~h}$ in a muffle furnace, with a mean heating rate of $17^{\circ} \mathrm{C} \mathrm{min}^{-1}$. The masses obtained at the beginning and end of the procedure were important for determining yield parameters on 
charcoal (ACY) and on coal volatile material (CVM) released during the carbonization according to the methodology of Ramos (2005) [10].

\section{Thermal activation}

In this step, the same ceramic vessels were used, this time with materials charred in the previous step and inserted in the muffle furnace for activation during $2 \mathrm{~h}$ at $800{ }^{\circ} \mathrm{C} \pm 1$, in average time of $57 \mathrm{~min}$, with a mean heating rate $17^{\circ} \mathrm{C} \mathrm{min}{ }^{-1}$. The mass obtained at the beginning and at end of the procedure were recorded to determine the parameters of average yield of activated charcoal (AYAC) and volatile material of activated charcoal (VMAC) released during calcination in accordance with Ramos (2005) [10].

\section{Characterization techniques}

AC2 was characterized as: moisture by ASTM D 286704 method, ash content by ASTM D 2866-94 method, pH by ASTM 3838-05 method, porosity in fixed bed ABNT NBR 9165-1985, bulk density according to ASTM D 2854-09 method, actual density and fixed carbon performed according to Ramos (2005) [10].

\section{Specific surface area}

The analysis of the specific surface area was obtained by the theory of multilayer in which nitrogen was used in its gaseous phase $\mathrm{N}_{2}$ at $77 \mathrm{~K}$, with approximately 40 adsorption-desorption cycles. The AC2 samples were treated at the temperature of $250{ }^{\circ} \mathrm{C}$ for $2 \mathrm{~h}$ before each test. The obtained data were analyzed by BET (Brunauer, Emmet and Teller) method, using a porosimeter of type MICROMERITICS TRISTAR-II USA.

\section{Porosimetry}

Data of the mean diameter and total pore volume were obtained from the $\mathrm{N}_{2}$ adsorption isotherm in gas phase at $77 \mathrm{~K}$ with adsorption-desorption cycles by the method of Barrett, Joyner and Halenda (BJH) using a MICROMERITICS TRISTAR-II USA porosimeter.

\section{Scanning electron microscopy (SEM) coupled with Energy dispersive $X$-ray spectroscopy (EDS)}

The SEM analysis was performed on electron microscope, model LEO-1430-USA; conditions for images of secondary electrons (ES) with beam current of $90 \mu \mathrm{A}$ at constant voltage of $20 \mathrm{kV}$, working distance of $15 \mathrm{~mm}$; AC2 samples were coated with a thin layer of platinum in sputter Emitech K550-USA.

\section{$X$-ray diffraction}

The analysis for phase identification was carried out on the samples by the total powder method using an X-ray diffractometer model X'PERT PRO MPD of
Table 1 Characterization of activated charcoal from Brazil-nut bark

\begin{tabular}{lll}
\hline Properties & Results & Standart Deviation \\
\hline Volatile material of charcoal (\%) & 49.2823 & 3.6226 \\
Yield of charcoal (\%) & 50.7176 & 3.6226 \\
Volatile material of activated carbon(\%) & 71.8145 & 3.6389 \\
Yield of activated charcoal (\%) & 28.1855 & 3.6389 \\
Moisture (\%) & 8.0385 & 0.2154 \\
Ash (\%) & 4.8475 & 0.0858 \\
Fixed carbon (\%) & 23.3379 & 0.5813 \\
pH & 10.10 & 0.0141 \\
Real density $\left(\mathrm{g} \mathrm{cm}^{-3}\right)$ & 0.9556 & 0.0028 \\
Bulk Density $\left(\mathrm{g} \mathrm{cm}^{-3}\right)$ & 0.4728 & 0.0089 \\
Porosity (\%) & 50.5209 & 0.9254 \\
\hline
\end{tabular}

PANALYTICAL- USA, with a goniometer PW 3050/60 $(\theta-\theta)$ with $\mathrm{X}$-ray ceramic tube with copper anode $\mathrm{Cu}$ $\left(K \alpha_{1}=1.540598 \AA\right)$, model PW 3373/00 with fine focusing, Ni K $\beta$ filter, $2200 \mathrm{~W}, 40 \mathrm{kV}$ and $40 \mathrm{~mA}$. For samples, the following were used: a sweep angle from $5^{\circ}$ to $75^{\circ}$, a voltage of $40 \mathrm{kV}$ and current of $30 \mathrm{~mA}$, a step size of $0.0170{ }^{\circ}$ and a time/step of $10 \mathrm{~s}$, and a fixed divergent and anti-scatter.

\section{Surface functional groups}

The surface chemical properties of charcoal were determined by the acidity or basicity, which can be altered when in liquid and gaseous phases if oxidising agents exist in its structure, which when treated with solutions such as nitric acid, sodium hypochlorite or hydrogen peroxide modify the nature and the amount of oxygen in the complex surface of charcoal [9]. The

Table 2 Characterization of area, volume e diameter of AC2

\begin{tabular}{|c|c|c|}
\hline Parameters & Mean Values $f$ & $\overline{\text { Deviation }}$ \\
\hline BET Specific Area - $\mathrm{S}_{\mathrm{BET}}\left(\mathrm{m}^{2} \cdot \mathrm{g}^{-1}\right)$ & 464.835 & 9.7735 \\
\hline $\begin{array}{l}\text { Specific Area of a single point in } \\
P / P^{\circ}-S_{P / P^{\circ}}\left(m^{2} \cdot g^{-1}\right)\end{array}$ & 477.6824 & 0.2044 \\
\hline Langmuir Specific Area- $S_{\text {Langmuir }}\left(\mathrm{m}^{2} \cdot \mathrm{g}^{-1}\right)$ & 619.9551 & 3.8205 \\
\hline Pore volume $-V_{P / p^{\circ}}\left(\mathrm{cm}^{3} \mathrm{~g}^{-1}\right)$ & 0.2561 & $(-)$ \\
\hline $\begin{array}{l}\text { Accumulated volume of pores in the } \\
\text { adsorption - } V_{\text {BJH-Ads }}\left(\mathrm{cm}^{3} \mathrm{~g}^{-1}\right)\end{array}$ & 0.0662 & $(-)$ \\
\hline $\begin{array}{l}\text { Accumulated volume of pores in } \\
\text { desorption }-V_{\text {BJHDes }}\left(\mathrm{cm}^{3} \mathrm{~g}^{-1}\right)\end{array}$ & 0.0731 & $(-)$ \\
\hline Mean pore diameter -D (nm) & 2.2031 & $(-)$ \\
\hline $\begin{array}{l}\text { Mean pore diameter in } \\
\text { adsorption - } D_{\text {BJH-Ads }}(\mathrm{nm})\end{array}$ & 4.9227 & $(-)$ \\
\hline $\begin{array}{l}\text { Mean pore diameter in } \\
\text { desorption - } D_{\text {BJH-Des }}(\mathrm{nm})\end{array}$ & 4.0695 & $(-)$ \\
\hline
\end{tabular}




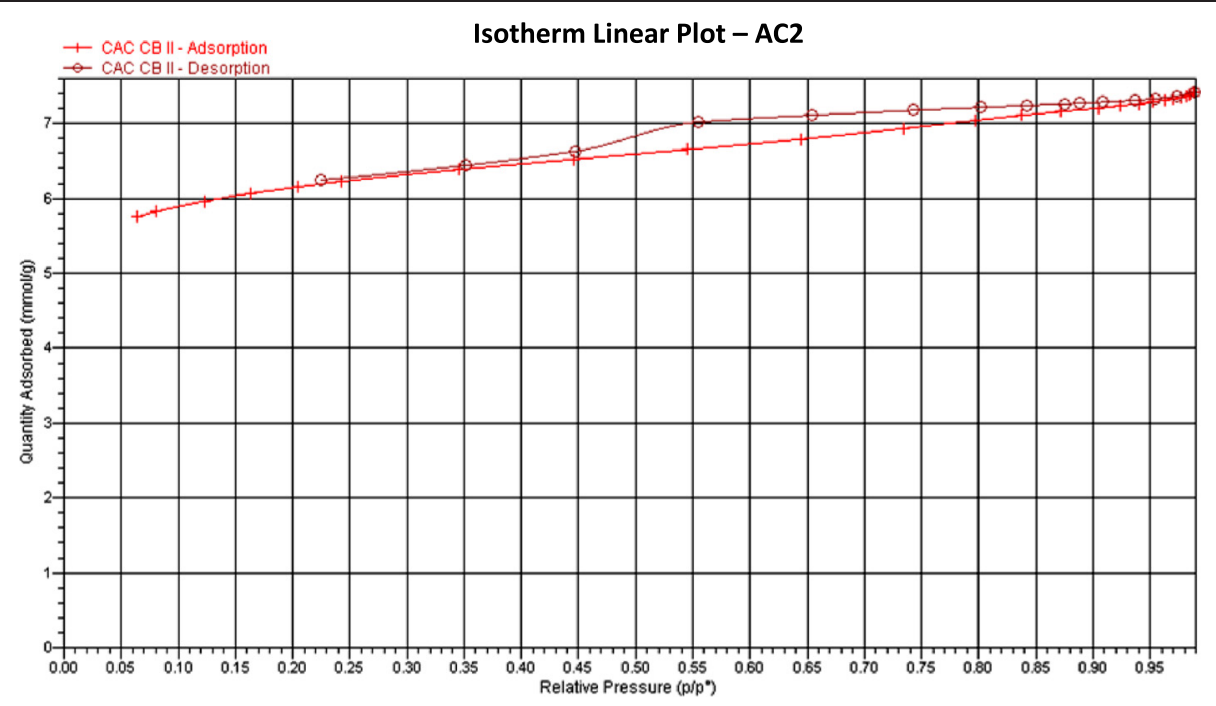

Fig. 1 Adsorption/desorption isotherm of $N_{2}$ by $A C 2$ at $77 \mathrm{~K}$

surface functional groups of AC2 were determined by Fourier transform infrared spectroscopy, (FTIR) and by Boehm method [19-22]. FTIR was carried out using the Thermo Scientific Nicolet apparatus, model IS10USA in the region 4000-400 $\mathrm{cm}^{-1}$. The carboxylic groups were obtained in tests with potassium hydrogen carbonate $\left(\mathrm{KHCO}_{3}\right)$. The amount of phenolic groups were found by the difference between groups found in titration tests with sodium hydroxide $(\mathrm{NaOH})$ and sodium carbonate $\left(\mathrm{Na}_{2} \mathrm{CO}_{3}\right)$, and lactonic groups by the

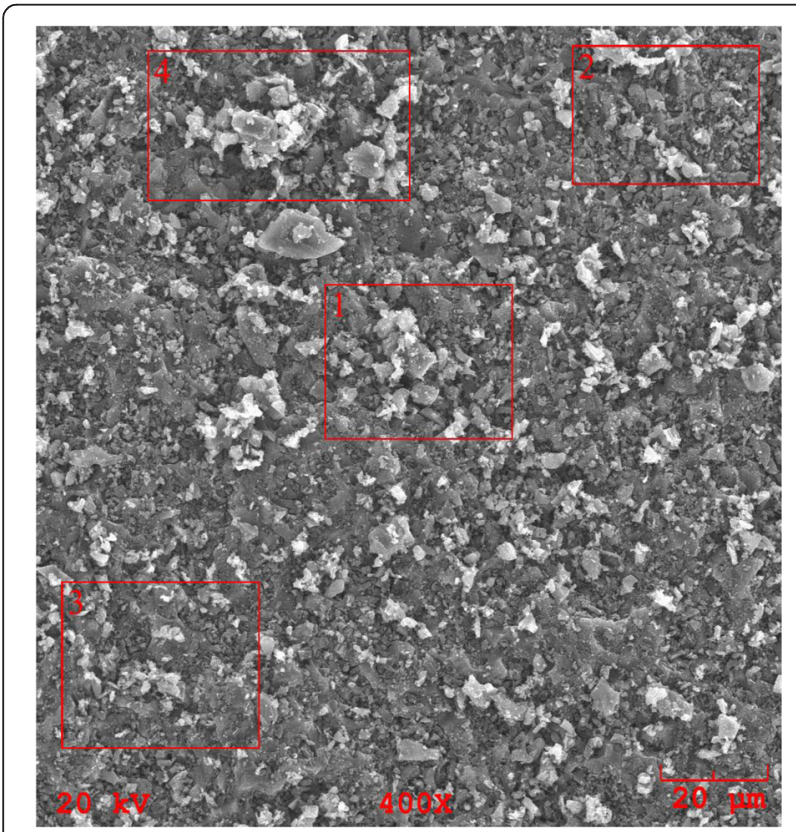

Fig. 2 Micrographs of AC2 taken by SEM. Highlighted squares indicate points for EDS difference of the groups found in tests with sodium carbonate $\left(\mathrm{Na}_{2} \mathrm{CO}_{3}\right)$ and potassium hydrogen carbonate $\left(\mathrm{KHCO}_{3}\right)$. To calculate the mass of acidic surface functional groups by Boehm method, Equation 1 was used [19-22]:

$$
A S F G=\frac{0,1 \times f \times\left(T_{b}-T\right) \times(50 / 20)}{w}
$$

Where: $\mathrm{T}_{\mathrm{b}}$, the volume of $\mathrm{HCl} 0.1 \mathrm{~mol} \mathrm{~L}^{-1}$ consumed by the solution of $\mathrm{NaOH} 0.1 \mathrm{molL}^{-1}$ for the blank experiment (mL); $\mathrm{T}$, the volume of $\mathrm{HCl} 0.1 \mathrm{~mol} \mathrm{~L}^{-1}$ consumed in different filtered solutions after the time of contact with $\mathrm{AC}(\mathrm{mL})$; $\mathrm{f}$, the factorization of $\mathrm{HCl} 0.1 \mathrm{~mol} \mathrm{~L}^{-1}$ and $\mathrm{w}$, the mass of AC used (g).

\section{Influence of $\mathrm{pH}$ on the adsorption of copper (II)}

To determine the influence of $\mathrm{pH}$ in solution in the adsorption process, the copper (II) solution was previously adjusted with standard solutions of $\mathrm{HCl}$ and $\mathrm{NaOH}$ $0.1 \mathrm{~mol} . \mathrm{L}^{-1}$, and the measured $\mathrm{pHs}$ into a potentiometer of countertop HANNA in the ranges of: $3.4 ; 4.01 ; 5.09$ and 6.01. The experiments were performed in duplicate for each $\mathrm{pH}$ range, keeping constants the initial concentration $\left(50 \mathrm{mg} \mathrm{L}^{-1}\right.$ of $\left.\mathrm{Cu} \mathrm{II}\right)$, volume of the solution $(100 \mathrm{~mL})$, solution temperature $\left(27.2^{\circ} \mathrm{C}\right)$, particle diameter $(0.595<\mathrm{D}<1.19 \mathrm{~mm})$, mass in grams of the adsorbent $(1.0 \mathrm{~g})$ and agitation frequency $(150 \mathrm{rpm})$. Then the samples were filtered and stored for determining the final concentration by atomic absorption.

\section{Influence of CA2 particle diameter in adsorption of copper (II)}

To determine the effect of CA2 particle diameter, granulometric studies were performed using sieves with mesh 14 , 


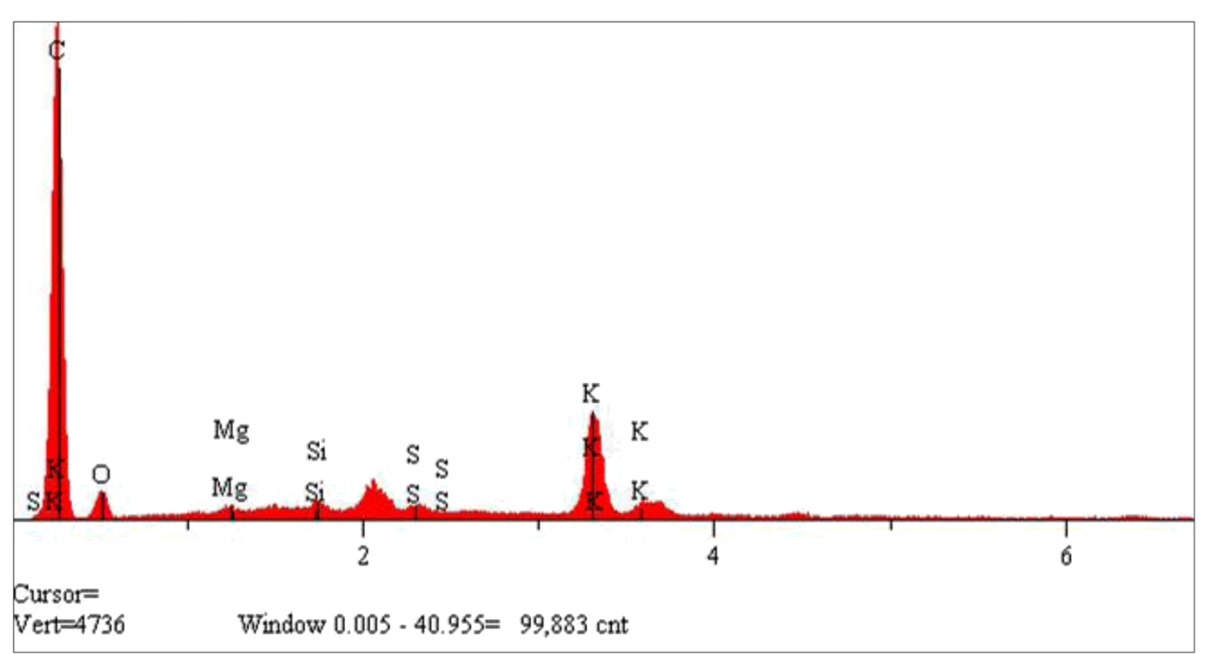

Fig. 3 AC2 spectrum obtained by EDS

28 and 48 (1.19 mm, $0.595 \mathrm{~mm}$ and $0.297 \mathrm{~mm}$ ) according to the Brazilian Association of Technical Norms (ABNT, Associação Brasileira de Normas Técnicas). Assays were performed in duplicate where the particle size varied within a range of 0.595 to $1.19 \mathrm{~mm}$ (D > $1.19 \mathrm{~mm}$; 0.595 < $\mathrm{D}<1.19 \mathrm{~mm}$ and $\mathrm{D}<0.595 \mathrm{~mm}$ ). For this study, initial concentration (50 mg. $\mathrm{L}^{-1}$ of $\mathrm{Cu}$ II), volume of the solution $(100 \mathrm{~mL})$, solution $\mathrm{pH}(5.47)$, solution temperature $\left(27.2^{\circ} \mathrm{C}\right)$, mass in grams of the adsorbent $(1.0 \mathrm{~g})$, contact time (60 $\mathrm{min})$ and agitation frequency $(150 \mathrm{rpm})$ remained constant. The samples were then filtered and stored for determining the final concentration by atomic absorption.

\section{Influence of the contact time of CA2 in solution in the adsorption of copper (II)}

For studying the contact times of CA2 assays were performed in duplicate and adsorption times evaluated at $1,2,5,8,10,20,30,60,90$ and $120 \mathrm{~min}$. The initial concentration (50 mg. $\mathrm{L}^{-1}$ of $\mathrm{Cu}$ II), volume of the solution $(100 \mathrm{~mL})$, solution $\mathrm{pH}$ (5.47), Solution temperature $\left(27.2{ }^{\circ} \mathrm{C}\right)$, particle diameter $(0.595<\mathrm{D}<1.19 \mathrm{~mm})$, mass in grams of the adsorbent ( $1.0 \mathrm{~g})$ and agitation frequency (150 rpm) were maintained as constants. The samples

Table 3 Chemical composition of AC2

\begin{tabular}{lllll}
\hline Elements & Point 1 & Point 2 & Point 3 & Point 4 \\
\hline $\mathrm{C}$ & 66.446 & 69.008 & 69.872 & 70.754 \\
$\mathrm{O}$ & 17.614 & 16.86 & 18.163 & 16.515 \\
$\mathrm{Mg}$ & 0.352 & 0.414 & 0.327 & 0.269 \\
$\mathrm{Si}$ & 0.439 & 0.401 & 0.541 & 0.493 \\
$\mathrm{~S}$ & 0.628 & 0.65 & 0.511 & 0.503 \\
$\mathrm{~K}$ & 14.521 & 12.668 & 10.586 & 11.465 \\
Total & 100 & 100 & 100 & 100 \\
\hline
\end{tabular}

were then filtered and stored for determining the final concentration by atomic absorption.

\section{Influence of the equilibrium concentration}

To study the equilibrium concentration in the adsorption process using CA2 as the adsorbent to remove $\mathrm{Cu}$ (II) of aqueous solution, the adsorption assays were performed in duplicate. For these experiments, $1.0 \mathrm{~g}$ of charcoal with diameter $0.595<\mathrm{D}<1.19 \mathrm{~mm}$ were used, which were placed in Erlenmeyer of $250 \mathrm{~mL}$ containing $100 \mathrm{~mL}$ of aqueous solution of $\mathrm{Cu}$ (II) at the initial concentrations $5,10,20,30,50,100,150$ and $200 \mathrm{mg} . \mathrm{L}^{-1}$ with $\mathrm{pH}$ equal to 5.46 , temperature $27.2^{\circ} \mathrm{C}$ and contact time of $60 \mathrm{~min}$. The flasks were closed with a plastic film and excited at a frequency of $150 \mathrm{rpm}$. After said time, the samples were filtered for the determination of final concentration by atomic absorption. With equilibrium concentration data from all the tests it was possible to calculate the percentage of removal of $\mathrm{Cu}$ (II) by Equation (2):

$$
\mathrm{R}(\%)=\left[\frac{\mathrm{C}_{\mathrm{i}}-\mathrm{C}_{\mathrm{e}}}{\mathrm{C}_{\mathrm{i}}}\right] \mathrm{x} 100
$$

Where $\mathrm{C}_{\mathrm{i}}$ : initial concentration of $\mathrm{Cu}$ (II) $\left(\mathrm{mg} \cdot \mathrm{L}^{-1}\right.$ ) and $\mathrm{C}_{\mathrm{e}}$ : final concentration or equilibrium concentration $\mathrm{Cu}$ (II) $\left(\mathrm{mg} \cdot \mathrm{L}^{-1}\right)$.

With regard to the study of the amount of copper (II) adsorbed by mass of charcoal at equilibrium, the equation (3) was used:

$$
\mathrm{Qe}=\frac{(\mathrm{Ci}-\mathrm{Ce}) \times \mathrm{V}}{\mathrm{M}}
$$

Where $\mathrm{Q}_{\mathrm{e}}$ : amount of $\mathrm{Cu}$ (II) adsorbed (mg adsorbate/g adsorbent);

$\mathrm{C}_{\mathrm{i}}$ : initial concentration of $\mathrm{Cu}(\mathrm{II})\left(\mathrm{mg} \mathrm{L}^{-1}\right)$; 


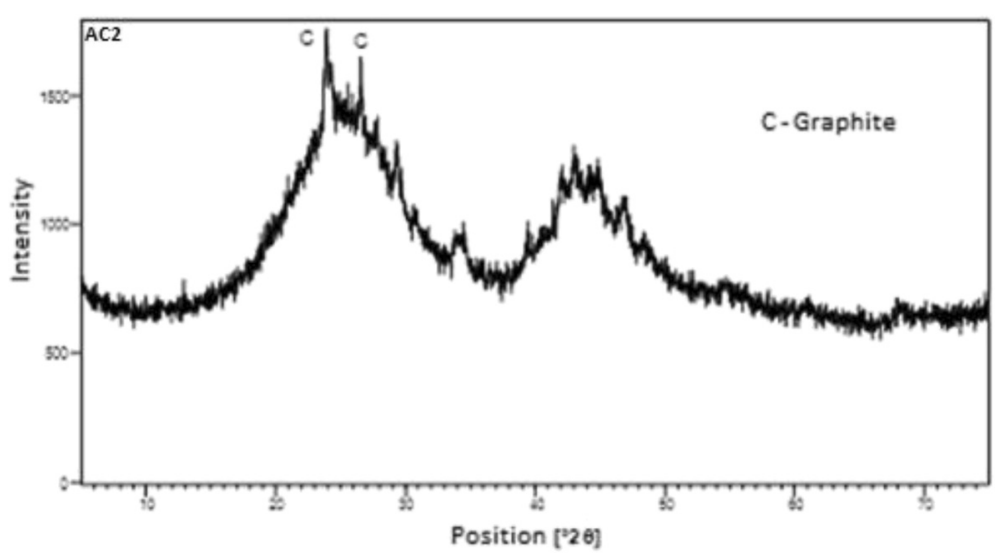

Fig. 4 X-Ray diffraction of AC2

$\mathrm{C}_{\mathrm{e}}$ : final concentration or equilibrium concentration of $\mathrm{Cu}$ (II) $\left(\mathrm{mg} \mathrm{L}^{-1}\right)$;

$\mathrm{V}$ : volume of the solution (L) and M: mass of charcoal CA2 (g).

\section{Results and discussion}

The quality of absorbent is determined by its physical and chemical properties: density, moisture and chemical composition (fixed carbon, ash and volatiles). Table 1 shows the results of the experimental tests of characterization of the AC2. As might be expected, charcoal presented basic characteristics after having been subjected to an activation temperature of $800{ }^{\circ} \mathrm{C}$. The basic absorbent developed basic oxides on its surface and in its ashes, which are responsible for the rise in $\mathrm{pH}$ when in solution, and thus adsorb acidic compounds [23].

Results of AC2 properties were very close to the values of charcoals from other vegetable precursors presented in Table 2. The absorbents were characterized by a large surface area in the range $300-4000 \mathrm{~m}^{2} \mathrm{~g}^{-1}$ evaluated by the BET method and are higher when mixed with solvent. ${ }^{7}$ Specific surface areas of the AC2 were found in the range of particle sizes of 200 mesh, and analyzed by BET $\left(\mathrm{S}_{\mathrm{BET}}\right)$ method, relative pressure $\left(\mathrm{S}_{\mathrm{P} / \mathrm{P}^{\circ}}\right)$ and Langmuir $\left(\mathrm{S}_{\text {Langmuir }}\right)$. The results obtained were $464.835 \mathrm{~m}^{2} \mathrm{~g}^{-1}$ specific surface (BET method).

AC2 is evenly comprises mostly mesopores with an average diameter of $2.2031 \mathrm{~nm}$ shown in Table 2. Mean diameter and total pore volume were determined by the $\mathrm{BJH}$ method (Barret, Joyner and Halenda), through gas adsorption analysis using $\mathrm{N}_{2}$ at $77 \mathrm{~K}$ to obtain a full isotherm (adsorption/desorption) of $\mathrm{N}_{2}$ with partial pressures ranging from $0.06 \mathrm{P} / \mathrm{P}^{\circ}$ to $0.99 \mathrm{P} / \mathrm{P}^{\circ}$ (Fig. 1), which when compared with the Brunauer classification is classified as a type II isotherm [24].

Type II isotherm is characteristic of a physical or reversible type adsorption, and tend to form multilayer adsorption. It is observed in the isotherm a loop similar to the hysteresis type $\mathrm{H} 4$, which is related to the mechanism of condensation of $\mathrm{N}_{2}$ in the mesopore. According to the IUPAC classification, this H4 hysteresis loop is associated with the presence of wedge-shaped micro and meso pores, cones and/or parallel plates and cylindrical capillaries open at both ends [25].

Scanning electron microscopy (SEM) coupled with Energy dispersive $\mathrm{X}$-ray spectroscopy (EDS)

Figure 2 shows a scanning electron microscopy (SEM) image of the sample. The image of absorbent was enlarged 400 times, showing a homogeneously porous structure. With EDS (energy dispersive X-ray spectroscopy) coupled with SEM, a semiquantitative analysis of the chemical elements present in the structure of the obtained charcoal was possible, through the four points highlighted in the picture. EDS (Fig. 3) shows the most intense bands corresponding to elements $\mathrm{C}, \mathrm{O}$ and $\mathrm{K}$ that can be considered as the natural species present in the bark of the Brazil-nut and that may influence the processes of ion exchange when charcoal is used as adsorbent. Other elements were also found in lower concentrations such as $\mathrm{Mg}, \mathrm{S}$ and $\mathrm{Si}$, as seen in Table 3. The amount of silicon found in this absorbent has a significant influence on the values of ash and moisture.

\section{X-ray diffraction}

In the X-ray diffraction pattern shown in Fig. 4, it is observed that the dominant phase is mineral graphite

Table 4 Results of Boehm titration

\begin{tabular}{lll}
\hline Functional groups & MASFG $^{a}(\%)$ & Deviation \\
\hline$-\mathrm{COOH}$ & 17.91 & 0.023 \\
$-\mathrm{COOR}$ & 3.62 & 0.037 \\
$-\mathrm{OH}$ & 78.48 & 0.003
\end{tabular}

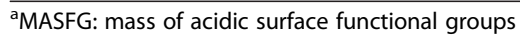


(carbon graphite) with characteristic peaks in the range of 23.89 to $26,58^{\circ}$. The amorphous materials (non-crystalline) are presented in large quantities, which can be observed in the elevation of the bottom line.

\section{Surface functional groups}

To determine the functional groups methods such as Fourier transform infrared spectroscopy (FTIR) and Boehm titration were adopted. Table 4 shows the results from the Boehm titration of AC2. Using Equation 1, it was possible to quantify the percentage masses of acidic surface functional groups in charcoal, where it was possible to identify larger amount of phenolic hydroxyl groups (78.48 \%) compared with carboxylic groups (17.91\%) and lactones (3.48 \%). According to Liu et al. (2007) [26], phenolic hydroxyl groups and lactones dissociate at higher $\mathrm{pH}$ values than carboxylic groups. Observing FTIR spectrum (Fig. 5), the absorption bands around 1710 to $1760 \mathrm{~cm}^{-1}$ indicate the peaks relating to carboxyl groups $(-\mathrm{COOH})$; the band from 1340 to $1480 \mathrm{~cm}^{-1}$ indicating the presence of phenolic hydroxy groups (-OH); around $1675 \mathrm{~cm}^{-1}$ to $1775 \mathrm{~cm}^{-1}$ indicating the presence of lactone groups (-OOR) and quinones (Bansal and Goyal, 2005) [8].

\section{The influence of $\mathrm{pH}$ on $\mathrm{Cu}$ (II) adsorption}

The values of adsorbed metal $(\mathrm{Qe})$ and the removal efficiency $(\mathrm{R} \%)$ of the metal in the study were obtained by equations (2) and (3) respectively. During the procedure it was observed that the removal percentage of the $\mathrm{Cu}$ (II) was proportional to the increase in the $\mathrm{pH}$ range, as seen in Table 5, wherein all assays showed the removal percentage above $90 \%$, with the exception of $\mathrm{pH}$ in the range 6.01, in which occurred copper hydroxide precipitation, $\mathrm{Cu}(\mathrm{OH})_{2}$, which is not interesting for this
Table 5 The influence of $\mathrm{pH}$ on $\mathrm{Cu}$ (II) adsorption

\begin{tabular}{lllllll}
\hline $\mathrm{pH}$ & $\mathrm{A} \mathrm{C}_{\mathrm{e}}\left(\mathrm{mg} \mathrm{L}^{-1}\right)$ & $\mathrm{B} \mathrm{C}_{\mathrm{e}}\left(\mathrm{mg} \mathrm{L}^{-1}\right)$ & $\mathrm{C}_{\mathrm{e}}\left(\mathrm{mg} \mathrm{L}^{-1}\right)$ & $\mathrm{MSE}^{\mathrm{a}}$ & $\mathrm{Q}_{\mathrm{e}}\left(\mathrm{mg} \mathrm{g}^{-1}\right)$ & $\mathrm{R} \mathrm{( \% )}$ \\
\hline 3.04 & 2.33 & 2.11 & 2.22 & 0.11 & 3.75 & 95.56 \\
4.01 & 2.06 & 1.79 & 1.92 & 0.13 & 4.44 & 96.15 \\
5.09 & 1.85 & 1.73 & 1.79 & 0.06 & 4.53 & 96.42 \\
6.01 & 2.18 & 3.05 & 2.61 & 0.43 & 4.15 & 94.77 \\
\hline
\end{tabular}

Mean standard error

process. In this case, $\mathrm{pH}$ equal to 5.09 is considered best suited to continue adsorption study of the $\mathrm{Cu}$ (II) with $\mathrm{AC} 2$ by being the natural range of synthetic solution and have higher metal removal percentage $96.42 \%$.

\section{Influence of AC2 diameter of the particles in the $\mathrm{Cu}$ (II) adsorption}

The influence of particle diameter is an important parameter, since the variety of adsorbent materials has a better adsorption capacity with a smaller particle size, due to the opening of tiny channels which, consequently, directly influence the contact surface between the adsorbent and the adsorbate in solution [27]. The effect of particle diameter on the $\mathrm{AC} 2$ in $\mathrm{Cu}$ (II) adsorption is presented in Table 6. It is noticed that the removal efficiency for the three granulometric ranges chosen for this process has been considered, since all the results were above $90 \%$ of removal of $\mathrm{Cu}$ (II). Therefore, the intermediate range of $0.595<\mathrm{D}<1.19 \mathrm{~mm}$ was chosen for subsequent adsorption experiments.

\section{Influence of the contact time of AC2 in solution $\mathrm{Cu}$ (II) adsorption}

The results are shown in Table 7, and it is observed that the influence of the variation in contact time (adsorbent/ adsorbate) in the results of $\mathrm{Cu}$ (II) removal efficiency is

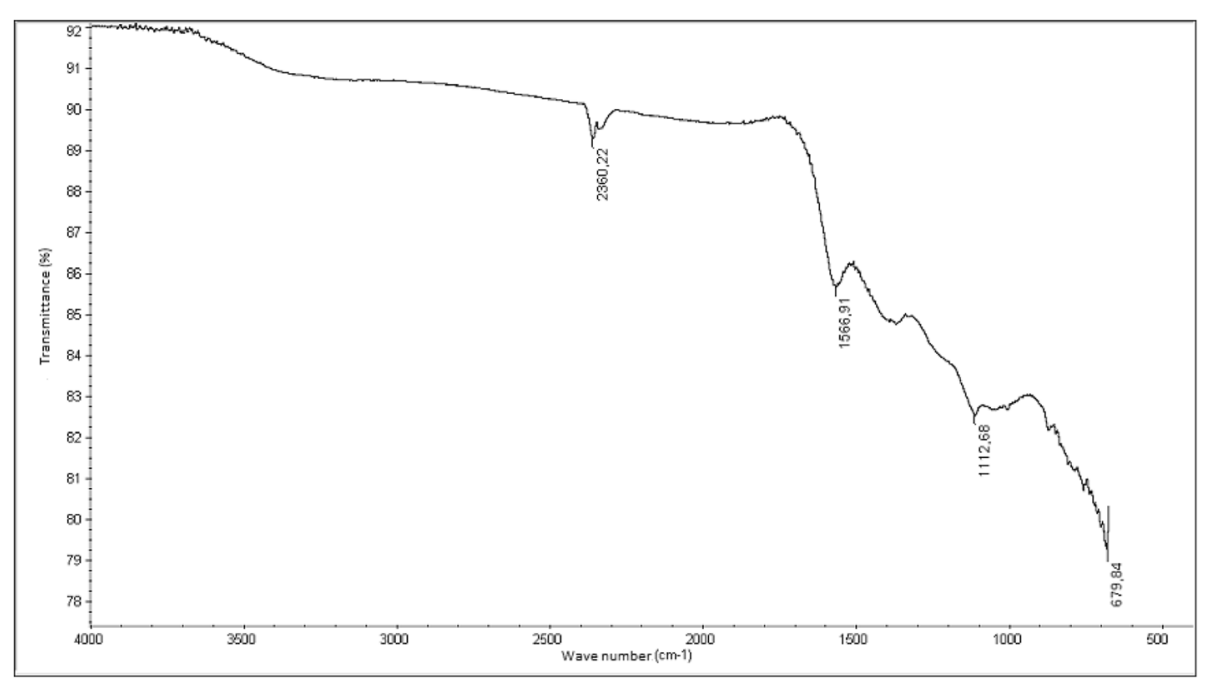

Fig. 5 FTIR spectrum of $A C 2$ 
Table 6 Influence of AC2 diameter of the particles in the Cu (II) adsorption

\begin{tabular}{lllllll}
\hline DIAMETER & $\begin{array}{l}\mathrm{AC}_{\mathrm{e}} \\
\left(\mathrm{mg} \mathrm{L}^{-1}\right)\end{array}$ & $\begin{array}{l}\mathrm{B} \\
\mathrm{C}_{\mathrm{e}}\left(\mathrm{mg} \mathrm{L}^{-1}\right)\end{array}$ & $\begin{array}{l}\mathrm{C}_{\mathrm{e}} \\
\left(\mathrm{mg} \mathrm{L}^{-1}\right)\end{array}$ & $\mathrm{MSE}^{\mathrm{a}}$ & $\begin{array}{l}\mathrm{Q}_{e} \\
\left(\mathrm{mg} \mathrm{g}^{-1}\right)\end{array}$ & $\mathrm{R}(\%)$ \\
\hline $\mathrm{D}>1.19 \mathrm{~mm}$ & 1.39 & 1.83 & 1.61 & 0.22 & 4.09 & 96.77 \\
$0.595<\mathrm{D}<1.19$ & 1.64 & 1.48 & 1.56 & 0.08 & 3.59 & 96.87 \\
$\mathrm{D}<0.595$ & 3.27 & 2.90 & 3.08 & 0.18 & 3.93 & 93.83 \\
\hline
\end{tabular}

${ }^{\mathrm{a}}$ Mean standard error

expressive, because it is observed that very fast equilibrium adsorption is achieved, whereas for all the agitation times, the removal percentage of above $90 \%$ was reached.

\section{Influence of the equilibrium concentration}

The removal efficiency of the $\mathrm{Cu}$ (II) by $\mathrm{AC} 2$ according to the varying of the initial concentration are shown in Table 8 , and the results showed values above $90 \%$ for concentrations 20, 30, 50, 100, 150 and $200 \mathrm{mg} \mathrm{L}^{-1}$, indicating positively the choice of the concentration equal to $50 \mathrm{mg} \mathrm{L}^{-1}$ of $\mathrm{Cu}$ (II) for experiments previously described. It was observed that the reduction in removal efficiency for the concentrations 5 and $10 \mathrm{mg} \mathrm{L}^{-1}$ is due to the lower mass transfer flow in the early stages of adsorption mechanism, as suggested by Melo (2012) [27].

\section{Conclusion}

In this study, it was possible to obtain thermally activated carbon from the bark of the Brazil-nut, an absorbent with mesoporous characteristics and satisfactory values of specific surface area. Moreover, it was possible to identify the presence of phenolic, carboxylic and lactonic groups on the surface of charcoal by means of infrared spectroscopy (FTIR) and Boehm titration. The properties of AC2 were similar to those coals from other vegetable precursors. Thus, the bark of the Brazil-nut, an abundant bio-residue, becomes a good alternative for

Table $\mathbf{7}$ Influence of the contact time of AC2 in solution in Cu (II) adsorption

\begin{tabular}{lllllll}
\hline $\mathrm{T}(\mathrm{min})$ & $\mathrm{A} \mathrm{C}_{\mathrm{e}}\left(\mathrm{mg} \mathrm{L}^{-1}\right)$ & $\mathrm{B} \mathrm{C}_{\mathrm{e}}\left(\mathrm{mg} \mathrm{L}^{-1}\right)$ & $\mathrm{C}_{\mathrm{e}}\left(\mathrm{mg} \mathrm{L}^{-1}\right)$ & $\mathrm{MSE}^{\mathrm{a}}$ & $\mathrm{Q}_{\mathrm{e}}\left(\mathrm{mg} \mathrm{g}^{-1}\right)$ & $\mathrm{R}(\%)$ \\
\hline 1 & 0.74 & 1.07 & 0.91 & 0.16 & 4.696 & 98.19 \\
2 & 0.56 & 0.52 & 0.54 & 0.02 & 4.637 & 98.91 \\
5 & 0.77 & 0.70 & 0.74 & 0.04 & 4.746 & 98.53 \\
8 & 0.99 & 1.09 & 1.04 & 0.05 & 4.536 & 97.92 \\
10 & 1.36 & 1.07 & 1.22 & 0.14 & 4.121 & 97.57 \\
20 & 1.52 & 1.22 & 1.37 & 0.15 & 4.365 & 97.26 \\
30 & 1.24 & 1.40 & 1.32 & 0.08 & 4.362 & 97.36 \\
60 & 1.06 & 1.17 & 1.12 & 0.05 & 4.589 & 97.77 \\
90 & 1.73 & 1.58 & 1.66 & 0.08 & 4.449 & 96.69 \\
120 & 2.12 & 1.97 & 2.04 & 0.08 & 4.643 & 95.92 \\
\hline Mean standard error & & & & &
\end{tabular}

a Mean standard error
Table $\mathbf{8}$ Influence of the initial concentration of Cu (II)

\begin{tabular}{lllllll}
\hline $\begin{array}{l}C_{i} \\
\left(\mathrm{mg} \mathrm{L}^{-1}\right)\end{array}$ & $\begin{array}{l}\mathrm{A} \\
\mathrm{C}_{\mathrm{e}}\left(\mathrm{mg} \mathrm{L}^{-1}\right)\end{array}$ & $\begin{array}{l}\mathrm{B} \\
\mathrm{C}_{\mathrm{e}}\left(\mathrm{mg} \mathrm{L}^{-1}\right)\end{array}$ & $\begin{array}{l}\mathrm{C}_{\mathrm{e}} \\
\left(\mathrm{mg} \mathrm{L}^{-1}\right)\end{array}$ & $\mathrm{MSE}^{\mathrm{a}}$ & $\begin{array}{l}\mathrm{Q}_{e} \\
\left(\mathrm{mg} \mathrm{g}^{-1}\right)\end{array}$ & $(\mathrm{R} \%)$ \\
\hline 5 & 0.85 & 0.65 & 0.75 & 0.09 & 0.419 & 84.99 \\
10 & 3.48 & 3.29 & 3.38 & 0.09 & 0.651 & 66.16 \\
20 & 0.45 & 0.69 & 0.57 & 0.12 & 1.877 & 97.16 \\
30 & 1.43 & 2.84 & 2.14 & 0.70 & 2.732 & 92.87 \\
50 & 3.34 & 3.02 & 3.18 & 0.16 & 4.386 & 93.64 \\
100 & 0.36 & 0.35 & 0.36 & 0.01 & 9.274 & 99.64 \\
150 & 0.47 & 0.79 & 0.64 & 0.16 & 13.999 & 99.58 \\
200 & 2.79 & 4.43 & 3.62 & 0.82 & 16.774 & 98.19 \\
\hline${ }^{a}$ Mean standard error & & & & &
\end{tabular}

the production of low cost activated carbon to be used in adsorption processes.

\section{Competing interests}

The authors declare that they have no competing interests.

\section{Authors' contributions}

This work was carried out in collaboration between all authors. Authors SSM, JEMD and DLS designed the study, wrote the protocol, involved in writing the first draft, participated in experiments and data collection. Authors JHG, DSBB, SSSM and JCTC managed the literature search, analyses of the study and manuscript preparation. Author SSM, CBRS, DCB and JSC performed the statistical analysis and also aided in data interpretation and was actively involved in reading the manuscript. All authors read and approved the final manuscript.

\section{Acknowledgements}

To CAPES for granting the scholarship. To the Laboratory of Environmental Processes (LPA/FEQ/UFPA), the Laboratory of Electron Microscopy (LABMEV/ IG/UFPA) and the Laboratory of Oil Chemistry (LCO/FQ/UFPA) of the Federa University of Pará, where it was possible to perform analyzes for the development of this work.

\section{Author details}

${ }^{1}$ Laboratory of Environmental Processes, Federal University of Pará, Rua Augusto Corrêa, 01, Belém, Pará 66075-110, Brazil. 'aboratory of Physical Chemistry, State University of Amapá, Av. Presidente Vargas, Campus I, 650, Macapá, Amapá 68900-070, Brazil. 'Laboratory of General and Analytical Chemistry, Federal University of Amapá, Rod. JK Km 2, s/n, Macapá, Amapá 68902-280, Brazil. Institute of Technology, Federal University of Pará, Rua Augusto Corrêa, 01, Belém, Pará 66075-110, Brazil.

Received: 20 November 2014 Accepted: 11 June 2015 Published online: 16 June 2015

\section{References}

1. Dabrowski A, Podkoscielny P, Hubicki Z, Barczak M. Adsorption of phenolic compounds by activated carbon - a critical review. Chemosphere 2005;58:1049-70

2. Sobhy MY. Removal of the hazardous, volatile, and organic compound benzene from aqueous solution using phosphoric acid activated carbon from rice husk. Chem Cen J. 2014:8:52.

3. Borba CE. Modeling the removal of heavy metals in a fixed bed column. Brazil: Master's Thesis. Campinas State university; 2006.

4. Peruzzo LC. Effect of adjuvants on the adsorption of dyes from textile industry effluents in fixed bed columns. In: Master's Thesis. Brazil: Technological Center, Federal University of Santa Catarina; 2003.

5. Lichawska ME, Bodek KH, Jezierska J, Kufelnicki A. Coordinative interaction of microcrystalline chitosan with oxovanadium (IV) ions in aqueous solution. Chem Cen J. 2014;8:50.

6. Di Bernardo L, Dantas ADB. Methods and Techniques in Water Treatment. São Carlos: RiMa; 2005. 
7. Franchi JG. The use of peat as an adsorbent for heavy metals: The case of contamination of the Ribeira River basin for lead and associated metals. In: Master's Thesis. Brazil: São Paulo Universty; 2004.

8. Bansal RC, Goyal M. Activated Carbon Adsorption. New York: Taylor \& Francis; 2005.

9. Yang RT. Adsorbents: Fundamentals and applications. New Jersey: John Wiley \& Sons; 2003

10. Ramos MAB. Ion removal $\mathrm{Cr}$ (III) from Aqueous Solutions by Adsorption on Activated Carbon and Biosorption and Immobilized Yeast. In: Master's Thesis. Brazil: Federal University of Pará; 2005.

11. Claudino A. Preparation of activated carbon from peat and its use in removing pollutants. In: Master's Thesis. Brazil: Technological Center, Federal University of Santa Catarina; 2003.

12. Tan IAW, Hameed BH, Ahmad AL. Equilibrium and kinetic studies on basic dye adsorption by oil palm fibre activated carbon. Chem Eng J. 2007;127:111-9.

13. Karagöz S, Tay T, Ucar S, Erdem M. Activated carbons from waste biomass by sulfuric acid activation and their use on methylene blue adsorption. Bioresour Technol. 2008;99:6214-22.

14. Pinto MVS, Silva DL, Saraiva ACF. Preparation and characterization of activated carbon from the seed Buriti (Mauritia flexuosa Lf) for evaluating the adsorption of a solution of Cu (II). Acta Amazonica. 2012;42:541-8.

15. Capobianco G, Coutinho AR, Luengo CA. Preparation of activated carbons with pores of nanometric dimensions from biomass precursors. Campinas-SP: AGRENER GD; 2004

16. Boniolo MR, Yamaura M, Monteiro RA. Residual biomass for removal of uranyl íons. Química Nova. 2010;33:547-51

17. Nunes AA, França AS, Oliveira LS. Activated carbons from waster biomass: an alternative use for biodiesel production solid residues. Bioresour Technol. 2009:100:1705-884

18. Homma AKO. Cemitério das Castanheiras. Ciência Hoje. 2004;34:202.

19. Boehm HP. Some aspects of the surface chemistry of carbon blacks and other carbons. Carbons. 1994:32:759-69.

20. Boehm HP. Surface oxides on carbon and their analysis: a critical assessment. Carbons. 2002:40:145-9.

21. Souza RS, Carvalho SML, Garcia Jr MRL, Sena RSF. Dsorption of chromium (VI) by granular activated carbon using a diluted solutions under controlled pH batch system. Acta Amazonica. 2009;39:661-8.

22. Siewsee N, Ola L, Kharidah M, Rabiha S, Norhayati $H$. Effect of roasting conditions on color development and Fourier transform infrared spectroscopy (FTIR-ATR) analysis of Malaysian-grown tropical almond nuts (Terminalia catappa L.). Chem Cent J. 2014;8:55.

23. Mohan D, Pittman Jr CU. Activated carbons and low cost adsorbents for remediation of tri- and hexavalent chromium from water. J Hazard Mater. 2006;137:762-811.

24. Gregg SJ, Sing KSW. Adsorption, Surface Area and Porosity. London: Academic Press; 1982.

25. Schettino Jr MA, Freitas JCC, Cunha AG, Emmerich FG, Soares AB, Silva PRN Preparations and characterization of chemically activated carbon from rice hulls. Química Nova. 2007;30:1663-8.

26. Liu SX, Chen X, Liu ZF, Wang HL. Activated carbon with excellent chromium (VI) adsorption performance prepared by acid-base surface modification. J Hazard Mater. 2007:141:315-9.

27. Melo SS. Produção de carvão ativado a partir da biomassa residual da castanha do Brasil (Bertholletia excelsa L.) para adsorção de cobre (II). In: Master's Thesis. Brazil: Institute of Technology of Federal University of Pará; 2012.

\section{Publish with ChemistryCentral and every scientist can read your work free of charge \\ "Open access provides opportunities to our colleagues in other parts of the globe, by allowing anyone to view the content free of charge." \\ W. Jeffery Hurst, The Hershey Company. \\ - available free of charge to the entire scientific community \\ - peer reviewed and published immediately upon acceptance \\ - cited in PubMed and archived on PubMed Central \\ - yours - you keep the copyright \\ Submit your manuscript here: \\ http://www.chemistrycentral.com/manuscript/ \\ Chemistry Central}

